After retirement, Sharples devoted his leisure to writing an up-to-date book on the "Diseases and Pests of the Rubber Tree" (Macmillan and Co., Ltd., London, 1936). This was a most notable addition to books on the diseases of tropical crop plants ; it is, in fact, a treatise on the principles of plant pathology with particular reference to rubber cultivation, and is eloquent testimony to the enlightened outlook which Sharples had on the problems of disease in plants. Unfortunately his health began to fail shortly before the publication of this book, and he died at the early age of forty-nine years. It is sad to think that after such a strenuous life in the East he did not live to enjoy the leisure he had so richly earned.

Personally, Sharples was something of a 'rough diamond', albeit his outspokenness became mellowed with age. He was entirely sincere and courageous in his opinions, and no one was ever a more loyal and kindly friend than he. His high achievement in spite of early handicaps is striking testimony to his sterling character. In an enervating climate he maintained his energy in an astonishing manner : tropical ennui never affected him. In any joint investigation he always pulled his weight, and generously shared credit with his colleagues. As a young man, he was keen on association football and in later life he was fond of tennis and golf. He married Edith Thornton in 1917, who survives him. There were two sons of the marriage, one of whom died a few years ago.

\section{Prof. J. G. Thomson}

Prof. John Gordon Thomson, director of the Department of Medical Protozoology at the London School of Hygiene and Tropical Medicine, whose death took place in London on August 13, was one of the few outstanding medical protozoologists in Great Britain. In addition he was, and continued to be until shortly before his death, a well-known investigator of tropical disease in the field.

Prof. Thomson commenced his career at the University of Edinburgh, where he graduated M.A. in 1903 and where he qualified in medicine with honours in 1908. Two years after qualifying he was appointed Durning-Lawrence research fellow in tropical medicine at Liverpool and later, 1912-13, pathological research fellow at the Liverpool School of Tropical Medicine. During his time at Liverpool, where he worked under Sir Ronald Ross, he carried out many researches on trypanosomiasis and on cultivation of the malaria parasites. His work in this last connexion, which was done largely in collaboration with his brother, Dr. D. Thomson, was perhaps that for which his name was best known.

In 1914 Prof. Thomson was appointed lecturer in protozoology at the London School of Tropical Medicine, but on the outbreak of the Great War he joined the Forces and proceeded in 1915 to Egypt, first as member of a commission to study bilharzia in that country and later as protozoologist to the Central Military Laboratory at Alexandria. On his return to England he was appointed officer in charge of the Malaria Research Laboratory at the War Office, where again he was associated with Sir Ronald Ross. Whilst in Egypt and later, he published many papers on amcebic dysentery and other intestinal protozoal conditions, as well as studies directed to the finding of satisfactory serological tests for malaria.

In 1918 Prof. Thomson took up the duties of the appointment at the London School of Hygiene and Tropical Medicine which he held at the time of his death; there he worked in post-graduate teaching and in the carrying out of many researches. In 1921 and again in 1922 he went on an expedition to study blackwater fever in Rhodesia. The results of these investigations were presented in a memoir, published by the School, which is now one of the best-known standard accounts of this disease. In 1924 he visited the West Indies, Honduras, Guatemala, Costa Rica and Panama. In 1934 he visited and carried out investigations in Nyasaland, studying more especially the indigenous malaria, and at various times he visited other tropical countries. In the intervals of travelling and demands made on his time by teaching, he published many papers on protozoological subjects and was joint author in Thomson and Robertson's "Text Book of Protozoology", a very useful and condensed source of information on the subjects dealt with.

Though Prof. Thomson worked at many different problems, the malaria parasites were always his favourite study, and even up to shortly before his death the nature of malarial immunity and drug treatment in malaria were much engaging his attention. Prof. Thomson's name is one familiar to research workers in tropical medicine both of British and of other nationalities, and his death will be a loss not only to his colleagues and many friends but also to a very wide circle where his work was known and appreciated.

\section{Prof. Luigi Pernier}

WE regret to record the death of Prof. Luigi Pernier, professor of archæology and the history of ancient art in the University of Florence, which took place in Rhodes at the age of sixty-two years in August last, while he was attending the Dante Alighieri course of "Alta Culture". His death is a great loss to archæological studies in Italy, more especially in connexion with the investigation of the sites of the early civilizations of the Mediterranean area.

Luigi Pernier was born in Rome on November 23, 1874. On completing his education, he was appointed to the Administration of Antiquities, and took part in the Italian archæological mission to Crete in 1900 , acting as director of the excavations at Festos. In 1909 he was appointed director of the Royal Italian School of Archæology at Athens and of the "Missioni Italiani in Oriente". While he was head of the School, archæological explorations were carried out in Crete, Delos, the Sporades and Euboea under his direction. In 1916 he was appointed director of the 